\title{
BEBAN GANDA ANEMIA PADA REMAJA SMPN TEMPURAN KABUPATEN KARAWANG
}

\author{
Nur Melani Sari ${ }^{1}$, Satrio Budi Wirawan ${ }^{2}$, Febria Putri Entijayanti ${ }^{3}$, Krusita Afrilliani ${ }^{4}$, \\ Firla Naza Deliesya ${ }^{5}$, Afifah Nurul Karimah ${ }^{6}$, dan Fania Fadhilah ${ }^{7}$ \\ ${ }^{1}$ Departemen Ilmu Kesehatan Anak, Rumah Sakit Hasan Sadikin \\ ${ }^{2}$ Fakultas Matematika dan Ilmu Pengetahuan Alam, Universitas Padjadjaran \\ ${ }^{3}$ Fakultas Teknologi Industri Pertanian, Universitas Padjadjaran \\ ${ }^{4}$ Fakultas Keperawatan, Universitas Padjadjaran \\ ${ }^{5}$ Fakultas Ilmu Sosial dan Politik, Universitas Padjadjaran \\ ${ }^{6}$ Fakultas Psikologi, Universitas Padjadjaran \\ ${ }^{7}$ Fakultas Kedokteran Gigi, Universitas Padjadjaran \\ E-mail: nur.melani.sari@unpad.ac.id
}

\begin{abstract}
ABSTRAK. Indonesia saat ini merupakan salah satu negara dengan prevalensi anemia yang masih tinggi terutama pada bayi, anak, dan remaja. Remaja mengalami beban ganda anemia diantaranya anemia defisiensi besi dan pembawa sifat talasemia. Anemia defisiensi besi dapat mempengaruhi fungsi otak, proses pertumbuhan, dan perkembangan serta menimbulkan efek penerununan sistem imun sehingga tubuh mudah lemas dan dapat menurunkan konsentrasi seseorang. Talasemia merupakan penyakit kronis yang diturunkan dari diturunkan dari orangtua kepada anaknya. Gejala kedua penyakit ini sangat sulit dibedakan yaitu anemia ringan dan kadang tidak bergejala. Angka kejadian kasus baru perlu dikendalikan, salah satunya dengan menggunakan uji tapis dan edukasi pada masyarakat. Kegiatan ini dilakukan berupa peningkatan pengetahuan tenaga kesehatan, guru dan siswa SMP mengenai penyakit talasemia dan anemia defisiensi besi. Metode yang digunakan adalah survei, observasi dan ceramah sosialisasi. Hasil penelitian ini memperlihatkan adanya peningkatan pengetahuan siswa SMP Tempuran, guru, dan tenaga kesehatan setelah dilakukan sosialisasi mengenai penyakit talasemia. Tingkat kesukarelaan siswa untuk mengikuti program skrining anemia yaitu 81,89\% di SMPN Tempuran 1, dan 66,67\% di SMPN Tempuran 2. Persentase anemia pada remaja putri adalah 11,68\%, sedangkan pada putra lebih tinggi yaitu $25,53 \%$.
\end{abstract}

Kata kunci: Anemia Defisien Besi, Talasemia, Program Uji Tapis.

ABSTRACT. Anemia is commonly found in Indonesia especially in infants, children and adolescents. Adolescent suffering a double burden of anemia including iron deficiency anemia and carriers of thalassemia. Iron deficiency anemia can affect brain function, growth and development process, and weaken the immune system. Thalassemia is a chronic disease passed down from parents to their children. The symptoms of these two diseases are very difficult to distinguish, namely mild anemia and sometimes asymptomatic. The incidence of new cases needs to be controlled, one of them is by using screening tests and education to the community. This program was carried out in the form of increasing the knowledge of health workers, junior high school teachers and students regarding thalassemia and iron deficiency anemia regarding talasemia screening policy from the Health Ministry. The method used is survey, observation and socialization lecture. The results of this study showed an increase in knowledge of Tempuran Middle School students, teachers, and health workers after socialization of thalassemia. The voluntary level of students to join the anemia screening program was $81.89 \%$ in Combat 1 Junior High School, and $66.67 \%$ in Combat Middle School 2. The percentage of anemia in adolescent girls was 11.68\%, while in boys it was $25.53 \%$.

Key words: Iron Deficiency, Anemia, Thalassemia, Screening test.

\section{PENDAHULUAN}

Defisiensi besi (DB) merupakan defisiensi mikronutrien yang paling sering terjadi di seluruh dunia, khususnya di Asia Tenggara dan Afrika Tengah (Stevens et al., 2013). Besi merupakan nutrisi penting dan berperan dalam pertumbuhan dan perkembangan. Kekurangan besi pada masa bayi hingga remaja dikaitkan dengan serangkaian masalah klinis dan perkembangan, meliputi defisit perkembangan saraf, penundaan pematangan respons batang otak terhadap pendengaran, serta gangguan memori dan perilaku. (Domello et al., 2014)

Masalah anemia defisiensi besi menjadi penting karena dapat mempengaruhi fungsi otak. Anemia pada remaja dapat menyebabkan keterlambatan pertumbuhan fisik, gangguan perilaku serta emosional. Hal ini dapat mempengaruhi proses pertumbuhan dan perkembangan sel otak sehingga dapat menimbulkan daya tahan tubuh menurun, mudah lemas dan lapar, konsentrasi belajar terganggu, prestasi belajar menurun serta dapat mengakibatkan produktifitas kerja yang rendah.

Saat ini prevalensi anemia pada bayi dan anak Indonesia masih berdasarkan data Riset Kesehatan Dasar (Riskesdas) Kementerian Kesehatan yaitu sekitar 21,7\%, terbagi pada kelompok usia $12-59$ bulan sebesar 28,1\%, 5-14 tahun 26,4\%, dan 14-24 tahun 18,2\%.(Kemenkes, 2014) Berdasarkan data Vitamin and Mineral Nutrition Information System (VMNIS) WHO, Indonesia tergolong kedalam kelompok prevalensi anemia moderat (sedang) untuk anak 6-59 bulan, yaitu 32\%.(WHO, 2015) Data populasi DB lainnya adalah survey Indonesia Life yang menujukkan penurunan prevalensi ADB dalam 1 dasawarsa terakhir dari $40-45 \%$ menjadi usia 31,4\% (0-5 tahun), 20,6\% (5-12 tahun), dan 15,8\% (12-<15 tahun). 
(Barkley, Kendrick, Codling, Muslimatun, \& Pach, 2015; "Hellen Keller International (Indonesia). Iron deficiency anemia in Indonesia. Jakarta; 1997; 1-16 ") Belum terdapat data populasi terbaru prevalensi anemia bayi dan anak di Indonesia. Sebagian penelitian ini bersifat lokal seperti yang dilakukan di pedesaan Sumatera Barat dan Kalimantan Selatan yang menunjukkan prevalensi yang lebih tinggi, yaitu 53,9\% dan 47,4\%.(Ringoringo, 2009; Widjaja, Widjaja, \& Santoso, 2014) Data prevalensi ini demikian penting, karena merupakan salah satu dasar pertimbangan untuk rekomendasi pemberian SB di setiap negara.

Beban lainnya adalah tingginya pembawa sifat talasemia di Indonesia, tanpa adanya program uji tapis maka prevalensi talasemia mayor semakin meningkat. Prevalensi pembawa sifat talasemia adanya berkisar 5-10\%. Pencegahan talasemia dilakukan melalui pencegahan pernikahan antara sesama penderita talasemia atau antara sesama pembawa gen Talasemia (Talasemia Minor). Hal ini hanya dapat dilakukan bila tiap individu mengetahui status talasemia masing-masing apakah normal, pembawa sifat atau menyandang talasemia. Pengobatan talasemia berlangsung seumur hidup, terdiri dari transfusi darah teratur, pengobatan kelebihan zat besi, akibat transfusi darah kronis, di samping juga dukungan psikososial untuk dapat meningkat kualitas hidupnya. Hal ini Keseluruhannya memerlukan biaya yg sangat mahal. Oleh karenanya program uji tapis merupakan suatu hal yang sangat mendesak. Pemerintah saat ini tengah menggodok program penapisan yang paling efektif. Jawa Barat sebagai daerah berpravelensi paling tinggi sudah sepantasnya melakukan gebrakan tindakan pencegahan. Distribusi pasien talasemia mayor yang tercatat di Jawa Barat (3180) pasienn tertinggi se Indonesia.(Kemenkes, 2017)

Talasemia merupakan salah satu penyakit kronis dan kasastropik lainnya yang menjadi bagian masyarakat di Indonesia. Untuk mengendalikan talasemia di masyarakat diperlukan suatu pedoman yang serentak di laksanakan di Indonesia. Pencegahan talasemia myor adalah upaya pencegahan kelahiran anak dengan talasemia mayor melalui program pengendalian talasemia mayor di pelayanan kesehatan tingkat pertama. (Kemenkes, 2017)

Uji tapis merupakan tindakan yang memerlukan biaya yang cukup tinggi sehingga diperlukan suatu algoritme yang paling sesuai yang cost effective dan dapat diaplikasikan kepada masyarakat. Pelaksanaan suatu program tentunya menghadapi berbagai pemasalahan dan tantangan di lapangan yang perlu diidentifikasi dan dicari solusinya. Kegiatan skrining dan deteksi dini ini memerlukan biaya sekitar 350-400 ribu/orang yang bila dibandingkan dengan biaya pengobatan seorang pasien Talasemia selama satu tahun diperkirakan mencapati sekitar 300 juta rupiah. Pada tahun 2017, kemkes telah mengeluarkan pedoman program uji tapis yang dilaksanakan di Puskesmas, kegiatan ini adalah salah satu upaya untuk persiapan pelaksanaan pedoman tersebut di fasilitas kesehatan tingkat pertama.(Kemenkes, 2017)

\section{METODE}

Kegiatan dilakukan dengan 4 tahapan metode, yaitu: Tahap 1: Sosialisasi Program Pengendalian

Dilakukan ceramah dengan evaluasi pre dan post test edukasi disertakan dengan sosialisasi melalui kuesioner kepada petugas kesehatan kec. Tempuran dan Lemah Dulur, Kepala Sekolah dan guru SMP N 1\&2 kecamatan Tempuran Karawang. Pemberian sosialisasi diharapkan agar petugas kesehatan dan semua staff yang ada disekolah mengetahui lebih dalam tentang anemia defisiensi besi dan talasemia. Tahap ini dianggap berhasil jika adanya peningkatan pengetahuan petugas kesehatan kec. Tempuran dan Lemah Dulur serta Kepala Sekolah dan guru sekolah SMP N 1\&2 kecamatan Tempuran Karawang.

\section{Tahap 2: Edukasi Siswa Smp Tempuran Tentang Talasemia \\ Dilakukannya penyampaian ceramah dan pemberian} leaflet. Ceramah diberikan dahulu setelah itu dilakukan pemberian leaflet kepada seluruh siswa/i kelas 1 SMP N 1\&2 Tempuran Karawang. Tahapan ini dianggap berhasil jika adanya peningkatan pengetahuan siswa/i terhadap anemia defisiensi besi dan talasemia setelah dilakukan edukasi.

\section{Tahap 3: Skrining Anemia Pada Anak Sekolah}

Diadakan pemeriksaan darah, hb, indeks eritrosit berdasarkan buku panduan pengendalian penyakit talasemia kem kes 2017 pada seluruh siswa/i kelas 1 SMP N 1\&2 Tempuran Karawang. Tahapan ini dianggap berhasil jika adanya keikutsertaan seluruh siswa/i kelas 1 SMP N 1\&2 Tempuran Karawang untuk mengikuti program skrining.

\section{Tahap 4: Pemberian Suplementasi dan Rujukan Untuk Pemeriksaan Talasemia}

Dilakukan pemberian suplemen dan rujukan untuk dilakukan pemeriksaan kepada siswa/i 1 SMP N 1\&2 Tempuran Karawang yang positif atau teridentifikasi mengalami anemia defisiensi besi. Tahapan ini dianggap berhasil jika ada siswa/i kelas 1 SMP N 1\&2 Tempuran Karawang yang teridentifikasi mengalami anemia defisiensi besi.

\section{HASIL DAN PEMBAHASAN}

Tabel 1. Hasil Kegiatan Tahap I Tingkat Pengetahuan Pegawai Terhadap Penyakit Talasemia dan Anemia Defisiensi Besi

\begin{tabular}{cccc}
\hline \multicolumn{2}{c}{\begin{tabular}{c} 
Rata-Rata Pengetahuan \\
Pegawai Puskesmas dan SMP \\
\multicolumn{2}{c}{ Tempuran }
\end{tabular}} & $\begin{array}{c}\text { Rata-Rata Pengetahuan Pegawai } \\
\text { Puskesmas dan SMP Lemah } \\
\text { Dulur }\end{array}$ \\
\hline Pre-Test & Post-Test & Pre-Test & Post-Test \\
\hline $76,3 \%$ & $86,07 \%$ & $78,71 \%$ & $90,2 \%$ \\
\hline
\end{tabular}

Terjadi peningkatan pengetahuan pegawai kesehatan dan guru SMP setelah dilakukan edukasi ceramah tentang penyakit talasemia dengan melakukan pre-test dan post-test. 
Tabel 2. Hasil Kegiatan Tahap II Tingkat Pnegetahuan Siswa SMP 1 dan 2 Tempuran Terhadap Penyakit Talasemia dan Anemia Defisiensi Besi

\begin{tabular}{cccc}
\hline $\begin{array}{c}\text { Rata-Rata Pengetahuan Siswa } \\
\text { SMP 1 Tempuran }\end{array}$ & \multicolumn{2}{c}{$\begin{array}{c}\text { Rata-Rata Pengetahuan Siswa } \\
\text { SMP 2 Tempuran }\end{array}$} \\
\hline Pre-Test & Post-Test & Pre-Test & Post-Test \\
\hline $55,15 \%$ & $53,90 \%$ & $49,55 \%$ & $55 \%$ \\
\hline
\end{tabular}

Terjadi peningkatan pengetahuan siswa SMP Tempuran setelah dilakukan edukasi ceramah tentang penyakit talasemia dengan melakukan pre-test dan post-test.

Tabel 3. Presentase Jumlah Siswa yang dilakukan pemeriksaan darah pada Tahap III

\begin{tabular}{ccc}
\hline Jumlah siswa & SMP 1 Tempuran & SMP 2 Tempuran \\
\hline Total Jumlah Siswa & 127 & 120 \\
\hline $\begin{array}{c}\text { Siswa yang dilakukan } \\
\text { pemeriksaan darah }\end{array}$ & 104 & 80 \\
\hline Presentase & $81,89 \%$ & $66,67 \%$ \\
\hline
\end{tabular}

Tabel 4. Tabel Karakteristik Subjek Skrining

\begin{tabular}{ccccccc}
\hline \multirow{2}{*}{ Usia } & \multicolumn{2}{c}{ Perempuan } & \multicolumn{2}{c}{ Laki-Laki } & \multicolumn{2}{c}{ Total } \\
\cline { 2 - 7 } & Jumlah & $\%$ & Jumlah & $\%$ & Jumlah & $\%$ \\
\hline 11 & 4 & $2,92 \%$ & 1 & $2,04 \%$ & 5 & $2,69 \%$ \\
12 & 83 & $60,58 \%$ & 27 & $55,10 \%$ & 110 & $59,14 \%$ \\
13 & 45 & $32,85 \%$ & 18 & $36,73 \%$ & 63 & $33,87 \%$ \\
14 & 5 & $3,65 \%$ & 2 & $4,08 \%$ & 7 & $3,76 \%$ \\
16 & 0 & 0 & 1 & $2,04 \%$ & 1 & $0,54 \%$ \\
\hline Total & 137 & $100 \%$ & 49 & $100 \%$ & 186 & $100 \%$ \\
\hline
\end{tabular}

Tabel 5. Hasil Kuesioner Anemia

\begin{tabular}{ccc}
\hline \multirow{2}{*}{ Pertanyaan } & SMPN1 Tempuaran & SMPN 2 Tempuran \\
\cline { 2 - 3 } & Modus & Modus \\
\hline 1 & 2 & 2 \\
2 & 3 & 3 \\
3 & 2 & 1 \\
4 & 3 & 3 \\
5 & 2 & 1 \\
6 & 2 & 2 \\
7 & 3 & 1 \\
8 & 3 & 3 \\
9 & 2 & 1 \\
10 & 3 & 3 \\
11 & 4 & 4 \\
12 & 4 & 4 \\
13 & 4 & 4 \\
14 & 4 & 4 \\
15 & 5 & 5 \\
\hline
\end{tabular}

Keterangan: 1= Ya (Kurang dari rata-rata), 2= Ya (Lebih dari ratarata), 3= Tidak, 4= untuk jawaban tidak 5= untuk jawaban iya Daftar pertanyaan pada lampiran

\section{Tabel 6. Tabel Kadar Hemoglobin}

\begin{tabular}{ccccccc}
\hline & \multicolumn{2}{c}{ Perempuan } & \multicolumn{2}{c}{ Laki Laki } & \multicolumn{2}{c}{ Total } \\
& Jumlah & $\%$ & Jumlah & $\%$ & Jumlah & $\%$ \\
\hline Anemia & 16 & $11,68 \%$ & 13 & $25,53 \%$ & 29 & 15,59 \\
Normal & 121 & $88,32 \%$ & 36 & $73,47 \%$ & 157 & $84,41 \%$ \\
Total & 137 & $100 \%$ & 49 & $100 \%$ & 186 & $100 \%$ \\
\hline
\end{tabular}

Tabel 7. Kadar Hemoglobin berdasarkan kadar MCV dan Indeks Mentzer

\begin{tabular}{cccc}
\hline & $\begin{array}{c}\text { Perempuan } \\
\mathrm{n}(16)\end{array}$ & $\begin{array}{c}\text { Laki-laki } \\
\mathrm{n}(13)\end{array}$ & Total \\
\hline $\mathrm{MCV}<80$ & 13 & 4 & 17 \\
$\mathrm{MCV}<80$ & & & \\
$\begin{array}{c}\text { Indeks } \\
\text { Menzter }<13\end{array}$ & 4 & 2 & 6 \\
\hline
\end{tabular}

Berdasarkan kuesioner anemia didapatkan bahwa asupan makanan mengandung besi tinggi kurang dan secara klinis tidak didapatkan gejala anemia (tabel 5). Tabel 6 dan 7 menunjukkan bahwa prevalensi anemia pada remaja laki-laki lebih tinggi dibandingkan perempuan, dengan kadar MCV yang rendah sebesar 17/29 sedangkan MCV rendah dan indeks menzter $<13$ adalah 6/29.

Kegiatan ini telah dilakukan tiga dari empat tahap yaitu, tahap pertama mengkaji tingkat pengetahuan staf terhadap penyakit talasemia dan anemia defisiensi besi. Pada tahap pertama dinilai tingkat pengetahuan Pegawai Puskesmas dan guru SMPN Tempuran didapatkan hasil nilai rata-rata saat pre test $76,3 \%$ dan saat post test $86,07 \%$. Hasil pretest menunjukan bahwa pengetahuan pegawai puskesmas dan guru SMPN Tempuran sudah cukup baik, mayoritas telah mengetahui mengenai pentingnya pengetahuan tentang talasemia dan anemia defisiensi besi.Hal yang sama pada staf Puskesmas Lemah Duhur yaitu hasil pre-test yang semula rata-rata saat pre test mendapatkan nilai $78,71 \%$ dan saat post test $90,2 \%$. $76,3 \%$ pada saat telah diberi edukasi hasil persentase naik menjadi $86,07 \%$ hasil tersebut dapat dikatakan baik. Media edukasi yang diberikan adalah berbentuk ceramah dan pembagian leaflet. Kedua metode tersebut dianggap cukup efektif dalam transfer pengetahuan sesuai dengan berbagai penelitian yang menunjukkan tidak terdapat perbedaan efektivitas metode ceramah dan leaflet.(Prihatiningsih, 2010). Bila dibandingkan antara kedua lokasi ceramah sosialisasi maka didapatkan bahwa tingkat pengetahuan tenaga kesehatan dan guru di Lemah Duruh lebih baik dibandingkan puskesmas Tempuran, hal tersebut dipengaruhi dengan tingkat pendidikan dari tenaga kesehatan. Sebagian besar tenaga kesehatan lemah duhur yang hadir pada kegiatan merupakan dokter. Anemia defisiensi besi dan talasemia merupakan kasus yang memiliki kompetensi tinggi dalam pendidikan dokter, perlu dipertimbangkan penguatan kurikulum terkait anemia defisiensi besi dan talasemia pada tenaga medis lainnya perawat, kebidanan, dan analis kesehatan. (KKI, 2012)

Tahap kedua, mengkaji tingkat pengetahuan siswasiswi SMPN 1 dan SMPN 2. Hal kurang maksimal didapatkan pada kedua kelompok. Hal ini terjadi mungkin karena keadaan kondisi fisik dari siswa-siswi SMPN 1 yang sudah lelah dari kegiatan sekolah ataupun baik kondisi lingkungan disekitar SMPN 1 yang tidak mendukung para responden untuk fokus menjawab pertanyaan dari 
post test yang telah diberikan. Bila dihubungkan dengan tingkat keikutsertaan program skrining Pada SMPN 1 jumlah presentase siswa yang dilakukan pemeriksaan darah sebanyak 81,89\% dan pada SMPN 2 sebanyak $66,67 \%$., dapat dikaatakan cukup tinggi. Namun pada anak usia ini sukarelaan berdasarkan rasa ingin tahu dan coba-coba bukan berdasarkan kesadaran yang cukup matang mengikuti program, dan pengetahuan baru yang diperoleh dari ceramah sosialisasi. Sehingga kebijakan skrining nantinya bila tetap dilaksanakan pada usia sekolah sebaiknya diperkuat yang bersifat instruksional melalui kerjasama antara Kementrian kesehatan dan Kementrian Pendidikan Dasar dan Menengah seperti program BIAS imunisasi pada anak sekolah, kegiatan berdasarkan instruksi bukan berdsarkan kesukarelaan. Pilihan lainnya adalah dengan mengganti target pada usia yang lebih matang sehingga pemeriksaan skrining diperkuat dengan kesiapan mental atas hasil yang mungkin didapatkan dari program tersebut. Program skrining talasemia dapat dibagi menjadi program skrining wajib dan sukarela. (Cousens, Gaff, Metcalfe, \& Delatycki, 2019).

Tahap ketiga dilakukan pemeriksaan darah dan pemberian kuesioner anemia remaja. Data hasil kuesioner menunjukkan bahwa masih banyak siswa yang tidak mengonsumsi makanan mengandung besi tinggi, diantaranya daging sapi dan hati ayam. Data diatas juga menunjukkan kurangnya asupan sayur dan buah. Hal ini mungkin disebabkan karena latar belakang sosial ekonomi, pengetahuan masyarakat terutama siswa tentang makanan mengandung besi serta lingkungan yang kurang sehingga memungkinkan siswa lebih mengonsumsi makanan yang ingin mereka makan seperti berbagai jajanan di sekolah. Hasil pemeriksaan skrining darah rutin menunjukkan bahwa prevalensi anemia adalah $15,59 \%$,pada remaja putri adalah $11,7 \%$ sedangkan pada remaja putra adalah $25,5 \%$. Hasil ini lebih rendah penelitian sporadis lainnya di pedesaan Indonesia yang menunjukkan prevalensi anemia mencapai $18,8 \%$ pada perempuan dan $11,1 \%$ pada lelaki(Widjaja, Widjaja, Santoso, Wonggokusuma, \& Oktaviati, 2014), sama halnya dengan prevalensi negara berkembang lainny.(Tesfaye, Yemane, Adisu, Asres, \& Gedefaw, 2015) Pada penelitian ini angka prevalensi remaja putra lebih tinggi berbeda dengan penelitian lainnya. Hal tersebut disebabkan jumlah laki-laki dan wanita kurang proporsional. Proporsi yang mengalami gambaran mikrositik dan indeks mentzer $<13$ adalah 6/13, dan target yang akan disuplementasi besi adalah 17 orang. Pemberian suplementasi akan diberikan selama 1 bulan dan ditinjau ulang perbaikan dari kadar hemoglobin. (Kemenkes, 2017)

\section{SIMPULAN}

Edukasi dan sosialisasi program harus dilakukan secara intens, walaupun secara kompetensi tenaga kesehatan memiliki kemampuan untuk melakukan deteksi namun karena kekerapan kasus yang kurang seringkali membuat tenaga kesehatan luput dari pemantauan. Hal tersebut ditambah lagi kekurangan fasilitas pemeriksaan penunjang dan analis di faskes primer, sehingga kasus ringan seperti anemia ringan ini yang bertumpu dari hasil pemeriksaan penunjang tidak dapat dilakukan.

Sasaran skrining yaitu anak kelas 1 SMP secara mental emosional belum matang, sehingga tampaknya proses edukasi mengenai anemia belum direspons secara utuh. Keikutsertaan untuk memeriksaan darah untuk skrining tidak berangkat dari kesadaran mandiri untuk mengetahui status kesehatan dirinya, namun lebih ke uji nyali bahwa mereka tidak takut prosedur pemeriksaan darah. Peranan guru dan teman sebaya sangat menentukan dalam proses ini. Proses skrining pada kelas 1 SMP pun sebaiknya melibatkan orang tua, karena sering kali keputusan untuk mengikuti atau tidaknya masih bergantung pada orangtua. Orang tua sebaiknya menjadi salah satu sasaran lainnya untuk dilakukan sosialisasi dan edukasi mengenai pentingnya skrining anemia pada remaja.

Hasil pemeriksaan skrining anemia akan dilanjutkan pada tahap selanjutnya yaitu pemeriksaan hasil $\mathrm{Hb}$. Anak dengan kadar $\mathrm{Hb}$ dibawah nilai normal akan diberikan suplementasi besi dan dinilai ulang 1 bulan kemudian. Bekerja sama dengan puskesmas terkait kita memantau apakah ada perbaikan kadar $\mathrm{Hb}$ pasca suplementasi,dan kepatuhan minum obat merupakan aspek lainnya yang akan kita nilai.

\section{UCAPAN TERIMAKASIH}

Puji syukur penulis panjatkan kepada Allah SWT yang telah memberikan rahmat beserta karunia-Nya sehingga penulis dapat menyelesaikan penulisan jurnal ini yang tidak lepas dari dukungan dana hibah internal UNPAD (HIU) dalam skema hibah Riset Fundamental Unpad. Kepada siswa KKNM (Kuliah Kerja Nyata) Unpad 2017-2018 yang telah ikut serta dalam mensukseskan kegiatan ini.

\section{DAFTAR PUSTAKA}

Barkley, J. S., Kendrick, K. L., Codling, K., Muslimatun, S., \& Pach, H. (2015). Anaemia prevalence over time in Indonesia: estimates from the 1997, 2000, and 2008 Indonesia Family Life Surveys. Asia Asia Pac J Clin N, 24(3), 452-455.

Cousens, N., Gaff, C., Metcalfe, S., \& Delatycki, M. (2019). Carrier screening for beta-thalassaemia: a review of international practice. European journal of human genetics : EJHG, 18(10), 1077-83.

Domello, M., Braegger, C., Campoy, C., Colomb, V., Decsi, T., Fewtrell, M., Goudoever, J. v. (2014). Iron requirements of infants and toddlers. $J P G N$ $119-129,119-129$. 
Hellen Keller International (Indonesia). Iron deficiency anemia in Indonesia. Jakarta; 1997; 1-16

Kemenkes. (2014). Riset Kesehatan Dasar.

Kemenkes. (2017). Pedoman pengendalian penyakit thalassemia. Jakarta: Kementrian Kesehatan RI

Direktorat Jenderal Pencegahan dan Pengendalian Penyakit Tidak Menular.

KKI. (2012). Standar pendidikan profesi dokter Indonesia.

Prihatiningsih, H.D.P. (2010). Studi Komparasi Metode Ceramah dan Leaflet terhadap Tingkat Pengetahuan dan Sikap Remaja tentang Vulva Hygiene di SMAN 10 Purwerojo. http://digilib. unisayogya.ac.id/1743/1/NASPUB.pdf

Ringoringo, H. P. (2009). Insidensi Anemia Defisiensi Besi pada Bayi Berusia 0-12 Bulan di Banjarbaru Kalimantan Selatan: studi kohort prospektif. Sari Pediatri, 11(1), 8-14.

Stevens, G., Finucane, M., De-Regil, L., Paciorek, C., Flaxman, S., Branca, F., Ezzati, M. (2013). Global, regional, and national trends in haemoglobin concentration and prevalence of total and severe anaemia in children and pregnant and nonpregnant women for 19952011: a systematic analysis of population-representative data. Lancet Glob Health, 1, 16-25.

Tesfaye, M., Yemane, T., Adisu, W., Asres, Y., \& Gedefaw, L. (2015). Anemia and iron deficiency among school adolescents: burden, severity, and determinant factors in southwest Ethiopia. Adolescent health, medicine and therapeutics, 6, 189-196.

WHO. (2015). The global prevalence of anaemia in 2011. Retrieved 1 March 2017, from http://www.who. int/nutrition/publications/

Widjaja, I.R., Widjaja, F.F., \& Santoso, L.A. (2014). Anemia among children and adolescent in a rural area. Pediatrica Indonesia, 54, 88-93.

Widjaja,I.R., Widjaja, F.F., Santoso, L.A., Wonggokusuma, E., \& Oktaviati. (2014). Anemia among children and adolescents in a rural area. Pediatrica Indonesia, 54, (2), 88-93. 